University of Nebraska - Lincoln

DigitalCommons@University of Nebraska - Lincoln

Faculty Publications from the Harold W. Manter Laboratory of Parasitology

$2-1988$

\title{
Letter to the Editors: Critical Comments on a Recent Letter to the Editors regarding the Use of Frozen Carcasses in Parasite Surveys
}

\author{
Danny B. Pence \\ Texas Tech University Health Sciences Center \\ John M. Aho \\ University of Georgia \\ Albert O. Bush \\ Brandon University \\ Albert G. Canaris \\ University of Texas at El Paso \\ Joseph A. Conti \\ Oglethorpe County Middle School \\ See next page for additional authors \\ Follow this and additional works at: https://digitalcommons.unl.edu/parasitologyfacpubs \\ Part of the Parasitology Commons
}

Pence, Danny B.; Aho, John M.; Bush, Albert O.; Canaris, Albert G.; Conti, Joseph A.; Davidson, William R.; Dick, Terry A.; Esch, Gerald W.; Goater, Timothy; Fitzpatrick, Wynn; Forrester, Donald J.; Holmes, John C.; Samuel, William M.; Kinsella, John M.; Moore, Janice; Rausch, Robert L.; Threlfall, William; and Wheeler, Terry A., "Letter to the Editors: Critical Comments on a Recent Letter to the Editors regarding the Use of Frozen Carcasses in Parasite Surveys" (1988). Faculty Publications from the Harold W. Manter Laboratory of Parasitology. 393.

https://digitalcommons.unl.edu/parasitologyfacpubs/393

This Article is brought to you for free and open access by the Parasitology, Harold W. Manter Laboratory of at DigitalCommons@University of Nebraska - Lincoln. It has been accepted for inclusion in Faculty Publications from the Harold W. Manter Laboratory of Parasitology by an authorized administrator of DigitalCommons@University of Nebraska - Lincoln. 


\section{Authors}

Danny B. Pence, John M. Aho, Albert O. Bush, Albert G. Canaris, Joseph A. Conti, William R. Davidson, Terry A. Dick, Gerald W. Esch, Timothy Goater, Wynn Fitzpatrick, Donald J. Forrester, John C. Holmes, William M. Samuel, John M. Kinsella, Janice Moore, Robert L. Rausch, William Threlfall, and Terry A. Wheeler 
LETTERS TO THE EDITORS . . .

\section{Critical Comments on a Recent Letter to the Editors Regarding the Use of Frozen Carcasses in Parasite Surveys}

We take exception to the Letter to the Editors by Shoop et al. (1987, Journal of Parasitology 73: 109). While these individuals are to be commended for their concern regarding the collection and reporting of data from parasite surveys and we agree with some of their concerns, we disagree with their assessment of the cause of the problem. We are concerned also that an uncritical acceptance of their viewpoint would restrict the use of a valuable technique.

Each of us has used frozen viscera for parasitological surveys for many years. We are well aware of the freezing artifact produced by ice crystal formation. Although formation of ice crystals after relatively slow freezing of specimens may be disruptive to the architecture at the cellular level (Lillie, 1965, Histologic technique and practical histochemistry, McGraw-Hill Book Company, New York, pp. 32-34), we have not experienced such changes at either the organ or organismic level. It is apparent that these changes are not sufficient to lyse, rupture, or otherwise destroy even the smallest cestodes, digeneans, or monogeneans. Examples with which some of us have had extensive experience include ancyrocephalid Monogenea of fishes, microhymenolepid Eucestoda of waterfowl, and microphallid Digenea of shore birds. These helminths are easily ruptured by routine manipulation or coverslip pressure, yet examination of thousands of specimens from frozen hosts, as well as fresh and formalin-fixed material, indicates little evidence of discernible structural damage and certainly not enough to preclude identification. For example, in studies on the Ancyrocephalidae of North America (Mizelle, 1936, American Midland Naturalist 17: 785-806; 1938, American Midland Naturalist 19: 465-470) there was extensive use of frozen material in taxonomic descriptions. Examination of type material from these studies presents little difficulty in species determination and the degree of "damage" is comparable to that produced by any of the other fixation techniques; only examination of living specimens provides more complete morphological data, but these are not usually available for study.

We concede that there may be some loss of affinity for stains in acanthocephalans, cestodes, monogeneans, and digeneans, some loss of scolex hooks in cestodes, and some loss of surface spination in digeneans, but there is no evidence for the actual loss of these helminths or of the severe degeneration of specimens ("unrecognizable mush") that form the basis for the concern expressed by Shoop et al. Rather, what these authors describe are postmortem autolytic changes in helminths collected from improperly handled host specimens. Such changes are encountered frequently in helminths from vertebrates, especially well-insulated homeotherms, frozen slowly by placing the whole carcass in the freezer, frozen viscera and carcasses subject to repeated thawing and refreezing, or by leaving the whole carcass in subfreezing ambient temperatures for varying periods of time prior to evisceration and freezing. Also, such changes occur frequently in gastrointestinal helminths from "freshly necropsied" carcasses of animals with high metabolic rates (birds, insectivores, chiropterans), large bodies (herbivores), well-developed insulation (waterfowl, furbearers), or rapid decomposition rates (most fish) examined within a few hours after death, especially in warm and humid climates. In these species, quickly eviscerated and promptly frozen viscera and carcasses are preferable to poorly attended "freshly" necropsied carcasses examined several hours after death.

A recently developed technique is the use of an ethyl alcohol-dry ice mixture (see Bush and Holmes, 1986, Canadian Journal of Zoology 64: 142-152) to "quickfreeze" viscera. Subsequently, viscera are kept in a freezer until necropsy. Helminth parasites, even the very small platyhelminths, are preserved in situ and in their exact location and natural postures at the instant of death. This technique is invaluable for ecological studies on populations and communities of helminth parasites. These specimens are in excellent condition, and are easily identified unfixed with phase-contrast microscopy or stained for subsequent identification. Even following prolonged periods of freezing, with or without dehydration due to "freezer burn," specimens can be rehydrated in water and subsequently identified. Soaking in a trisodium phosphate solution will enhance the subsequent staining of dehydrated specimens.

We believe that freezing of viscera, if properly applied, is an invaluable technique for obtaining and storing vertebrate specimens for parasite surveys. Logistical constraints related to time that can be spent in the field, distance from laboratory facilities, time required for adequate necropsies, size of the animal, etc., are factors that necessitate some form of intermediate storage of vertebrate specimens prior to their necropsy. Freezing or preservation in fixative are the only viable alternatives for the collection of such material. In our experience, working with fixed viscera is unpleasant, somewhat hazardous, and usually results in contracted specimens with adherent mucus that is difficult to remove. Additionally, small parasites such as recently recruited digeneans and cestodes that are in the lumen of the intestine and tissue-dwelling nematodes are difficult to recover and in cases of low parasite abundance, parasite occurrence may be, and abundance will be, underrepresented. Frozen material has none of these disadvantages.

We believe that even inadequately handled frozen material may be useful. Frozen specimens of rare or hard to obtain vertebrates may be available in no other condition, but these may still provide valuable data on parasites. We agree with Shoop et al. that authors using such material should be aware of its limitations, and they should warn the reader of its quality. While these authors state that "It is truly a disservice to the parasitological community when a paper is published purporting to have looked at all parasites of a particular 
host species when in fact the methodology only allowed adequate recovery of one or two parasitic groups (sic)," we contend that it is a greater disservice to the parasitological community to condemn unequivocally a method that has contributed so much to the knowledge of helminth faunas worldwide. This controversy could be resolved experimentally by comparing previously known numbers of helminths recovered from frozen versus freshly necropsied viscera. Because both methods are useful and therefore likely to be employed for some time, quantitative estimates of the relative error would be enlightening. Finally, we urge the Editors of parasitological journals to offer concurrent rebuttal and critical comments on Letters to the Editors such as the one by Shoop et al. prior to publication because (in these authors' own words) "once these ... [letters] are published they are difficult to recognize for what they are and disinformation such as this is misleading to colleagues."

Danny B. Pence, Department of Pathology, Texas Tech University Health Sciences Center, Lubbock, Texas 79430; John M. Aho, Savannah River Ecology Laboratory, University of Georgia, Drawer E, Aiken, South Carolina 29801; Albert O. Bush, Department of Zoology, Brandon University, Brandon, Manitoba, Canada R7A 6A9; Albert G.
Canaris, Department of Biological Sciences, University of Texas at El Paso, El Paso, Texas 79968; Joseph A. Conti, Oglethorpe County Middle School, Lexington, Georgia 30648; William R. Davidson, Southeastern Cooperative Wildlife Disease Study, Department of Parasitology, College of Veterinary Medicine, University of Georgia, Athens, Georgia 30602; Terry A. Dick, Department of Zoology, University of Manitoba, Winnipeg, Manitoba, Canada R3T 2N2; Gerald W. Esch, Timothy Goater, and Wynn Fitzpatrick, Department of Biology, Wake Forest University, Winston-Salem, North Carolina 27109; Donald J. Forrester, Department of Infectious Diseases, College of Veterinary Medicine, University of Florida, Gainesville, Florida 32610; John C. Holmes and William M. Samuel, Department of Zoology, University of Alberta, Edmonton, Alberta, Canada T6G 2E9; John M. Kinsella, 2108 Hilda Avenue, Missoula, Montana 59801; Janice Moore, Department of Zoology, Colorado State University, Fort Collins, Colorado 91330; Robert L. Rausch, Division of Animal Medicine, School of Medicine, University of Washington, Seattle, Washington 98195; William Threlfall, Department of Biology, Memorial University of Newfoundland, St. John's, Newfoundland, Canada A1B 3X9; and Terry A. Wheeler, Department of Environmental Biology, University of Guelph, Guelph, Ontario, Canada N1G 2W1. 